\title{
The Frontier in the Historical Development of the International Law of the Sea
}

\author{
Tullio Scovazzi
}

The historical development of the international law of the sea can be understood in the light of the interplay between different regimes, namely freedom of marine waters, coastal States' sovereignty over them and, recently, common heritage of mankind. ${ }^{1}$ In this perspective, considering that a 'frontier' is the limit that marks the distinction between areas subject to different regimes, a fundamental question is the determination of where a frontier is located and whether it should be moved elsewhere. While a frontier existed at all times, political, economic and other factors have influenced its establishment and its changes over time. The pace of legal evolution may vary from prolonged stillness to abrupt changes, depending on the period and the circumstances. However, all the attempts to establish a balance between the forces leading in divergent directions have been followed by subsequent evolutionary trends leading to an alteration of the balance.

This chapter will try to describe the different 'frontiers' that have been envisaged in international law of the sea. It will devote some attention also to the past, which remains often concealed under the dust of time. ${ }^{2}$

\section{2 Coastal Waters within the Theory of Freedom of the Sea}

At the time of the origins of international law of the sea, the notion of a frontier (in the sense of a maritime boundary to coastal waters) was not rejected altogether by those who supported the opposite theories of freedom or

1 This chapter is based largely on research for T Scovazzi, 'The Evolution of International Law of the Sea: New Issues, New Challenges' (2000) 286 Recueil des cours 122.

2 On the historical aspects of international law of the sea, see TW Fulton, The Sovereignty of the Sea (William Blackwood and Sons, 1911); JK Oudendijk, Status and Extent of Adjacent Waters: A Historical Orientation (Sijthoff, 1970). 
sovereignty of the sea. In the sixteenth century, England refused to recognize the claims of sovereignty over marine waters, such as those put forward by Spain and Portugal over entire oceans, by Denmark over the waters located between Norway, the Faroe Islands and Iceland (the so-called Danish seas) and by Venice over the Adriatic Sea. The instructions given in 1602 by Queen Elizabeth to the English representatives sent to meet the Danish envoys in Bremen can be remembered as the first plea for the concept of freedom of the sea:

Sometime in Speech Denmarck claymeth Propertie in that Sea as lying between Norway and Island, both sides in the Dominions of oure loving Brother the King, supposing thereby that for the Propertie of a whole Sea, it is sufficient to have the Bancks on both sides as in Rivers; Whereunto you may answere, that though Propertie of Sea in some small distance from the Coast, maie yeild some Oversight and Jurisdiction, yet use not Princes to forbid Passage or Fishing, as is well seen in our Seas of England and Ireland, and in the Adriaticke Sea of the Venetians, were We in ours, and they in theirs have Propertie of Command; and yet neighter We in ours, nor they in theirs, offer to forbid Fishing, much lesse Passage to Ships or Merchandize, the which by Law of Nations cannot be forbidden ordinarilie, neither it is to be allowed that propertie of Sea in whatsoever distance is consequent to the Banks, as it hapneth in small Rivers. ${ }^{3}$

While pleading for freedom of navigation and fishing, Queen Elizabeth conceded that the coastal State could exercise some authority 'within a small distance from the coast'.

Similar concepts were expressed a few years later by the Dutch scholar Huig de Groot (Hugo Grotius; $1583-1645)$. His booklet Mare liberum, ${ }^{4}$ published anonymously in 16o9, was decisive in establishing solid theoretical foundations for the principle of freedom of the sea. Among other arguments, Grotius

3 Text in T Rymer, Foedera, conventiones, literae, et cujuscunque generis acta publica, inter reges Angliae, et alios quosvis imperatores, reges, pontifices, principes, vel communitates, ab ineunte saeculo duodecimo, viz. ab anno 1101, ad nostra usque tempora, habita aut tractata (3rd ed, Hagae Comitis, 1739-1745), vol viI, part II, 25.

4 More precisely: Mare liberum sive de jure, quod Batavis competit ad Indicana commercia, dissertatio (Lugduni Batavorum, 16o9). The name of Grotius as the author appeared for the first time in a Dutch translation published in 1614. The Mare liberum was only chapter XII of an extensive treatise entitled De jure praedae commentarius that was found accidentally only in 1864 and published for the first time in 1868 (H Grotius, De jure praedae commentarius, ex auctoris codice descripsit et vulgavit (ed. HG Hamaker, Hagae Comitum, 1868)). 
developed a simple idea, based on the very nature of the sea: the regime of the sea must be founded on freedom of use for everybody, for it is impossible to occupy and delimit infinite and boundless natural elements, such as the air or marine waters:

Mare igitur proprium omnino alicujus fieri non potest, quia natura commune hoc esse non permittit, sed jubet. ${ }^{5}$

And further:

$[Q]$ uae publica juris gentium in legibus vocantur, hoc est communia omnium, propria nullius. Hujus generis est aër, duplici ratione, tum quia occupari non potest, tum quia usum promiscuum hominibus debet. Et eisdem de causis commune est omnium maris elementum, infinitum scilicet ita, ut possideri non queat, et omnium usibus accommodatum, sive navigationem respicimus, sive etiam piscaturam. ${ }^{6}$

Grotius had freedom of overseas navigation mostly in mind. Far from being attached to freedom of the sea as a conceptual dogma, he upheld a pragmatic approach to the problems he was facing. He clearly stated that his considerations applied to the immense ocean, and not to bays, straits and all waters that can be seen from the coast:

De oceano quaeritur, quem immensum, infinitum rerum parentem, coelo conterminum antiquitas vocat: cujus perpetuo humore non fontes tantum et flumina et maria, sed nubes, sed ipsa quodammodo sidera pasci veteres crediderunt: qui denique per reciprocas aestuum vices terram hanc, humani generis sedem, ambiens neque teneri neque includi potest, et possidet verius quam possidetur. In hoc autem oceano non de

5 Grotius, De jure praedae, ibid 220. In English translation: 'It is, then, quite impossible for the sea to be made the private property of any individual; for nature does not merely permit, but rather commands, that the sea shall be held in common'. H Grotius, Commentary on the Law of Prize and Booty, I (A Translation of the Original Manuscript of 1604 by Gwladys L Williams, Clarendon Press, 1950) 232.

6 Grotius, De jure praedae, above (n 5), 218; 'In the precepts of law of nations, too, such things are described as "public", that is to say, as the common possession of all men and the private possession of none. Air falls into this class for two reasons: first, because it is not possible for air to be made subject of occupancy; secondly, because all men have a common right to use of air'. Grotius, Commentary, above (n 5), 231. 
sinu, aut freto, nec de omni quidem eo quod e littore conspici potest, controversia est. ${ }^{7}$

He also conceded that fishing could be regulated in the hypothetical case of depletion of fish, while navigation was to be and remain free, as, unlike fishing, it leaves the sea unchanged:

Et si quicquam eorum prohibere posset, puta, piscaturam, qua dici quodammodo potest pisces exhauriri, at navigationem non posset, per quam mari nihil perit. ${ }^{8}$

In his general treatise De jure belli ac pacis, published in 1625, Grotius's ideas on the legal condition of the sea developed in the direction of admitting that a State can occupy a limited extent of coastal waters, this being something very different from the boundless oceans:

Videtur \& mare occupari potuisse ab eo, qui terras ad latus utrumque possideat, etiamsi aut supra pateat ut sinus aut ... ut fretum, dummodo non ita magna sit pars maris, ut non cum terris comparata portio earum videri possit. ${ }^{9}$

\section{Coastal Waters within the Theory of Sovereignty of the Sea}

Within a few years of the publication of the Mare liberum, a number of works were printed in favour of the opposite theory of the sovereignty of the sea,

7 Grotius, De jure praedae, above ( $\mathrm{n}_{5}$ ), 226; 'The subject of our discussion is the Ocean, which was described in olden times as immense, infinite, the father of created things and bounded only by the heavens; the Ocean, whose never-failing waters fed not only upon the springs and rivers and seas, according to the ancient belief, but upon the clouds also, and in a certain measure upon the stars themselves; in fine, that Ocean which encompasses the terrestrial home of mankind with the ebb and flow of its tides, and which cannot be held nor enclosed, being itself the possessor rather than the possessed. Moreover, the question at issue is not limited to some bay or strait located in the Ocean, nor even the entire expanse of its waters visible from the shore'. Grotius, Commentary, above ( $\left.\left.\mathrm{n}_{5}\right), 238\right)$.

8 Grotius, De jure praedae, above ( $\mathrm{n}_{5}$ ), 230; 'Yet again, even if it were possible to prohibit some particular act of this kind, such as fishing (for it may be maintained that the supply of fish is, in a sense, exhaustible), it would in any case be impossible to prohibit navigation, through which the sea loses nothing. Grotius, Commentary, above (n 5), 243.

9 H Grotius, De jure belli ac pacis libri tres (Parisiis apud Nicolaum Buon, 1625) book II, chap III, para viII. 
based on the assumption that the sea can also be occupied. Among Grotius' opponents, the Englishman John Selden (1564-1654) is often remembered. ${ }^{10}$ In 1625, when he wrote Mare clausum, England had radically changed its previous position on freedom of the sea. Under a proclamation adopted by King James I on 6 May 16o9, licences were required from foreign vessels engaged in fishing within an area generically designated by the expression 'our Coasts and Seas' of Great Britain, Ireland and the adjacent islands.

Before Selden, other notable authors, such as the Scotsman William Welwood $(1566-1624),{ }^{11}$ the Venetians Paolo Sarpi $\left(155^{2-1623}\right)^{12}$ and Giulio Pace da Beriga $\left(155^{-}-1635\right),{ }^{13}$ and the Portuguese Serafim Freitas (1570-1633), ${ }^{14}$ wrote in support of coastal State sovereignty over the sea. They engaged Grotius and his followers ${ }^{15}$ in a doctrinal dispute now known as 'the battle of books' (la bataille des livres).

These writers tried to demonstrate two propositions. First, that the sea is capable of occupation through appropriate means (for example, by a fleet). Second, that a given power, be it England, Spain, Portugal or Venice, had already acquired sovereignty over a specific ocean or sea. Even though the theorists of sovereignty of the sea believe that the coastal State is entitled to occupy a vast extent of waters, this does not exclude the existence of a 'frontier'. For instance, according to Welwood, the close link existing between the territory and the adjacent waters allowed an extension of sovereignty from the coast up to the limit of 100 miles. It is only beyond this limit that the high seas, open to everybody, begins. ${ }^{16}$ According to Sarpi, the extent of sovereignty over the sea

10 J Selden, Mare clausum seu de dominio maris libri duo (Londini, 1635).

11 W Welwod, An Abridgement of All Sea-Lawes (London, 1613); W Welwod, De dominio maris, juribusque ad dominium praecipue spectantibus, assertio brevis ac methodica (Cosmopoli, 1615).

12 P Sarpi, Opere varie del molto reverendo Padre F. Paolo Sarpi dell'Ordine dei Servi di Maria teologo consultore della Serenissima Repubblica di Venezia divise in due tomi (Helmstat, 1750). It includes the advice Dominio del mar Adriatico della serenissima repubblica di Venezia, originally written in 1612 for the Republic of Venice.

13 G Pace, De dominio maris Hadriatici disceptatio (Lugduni, 1619).

14 S de Freitas, De justo imperio Lusitanorum Asiatico (Vallisoleti, 1625). From 1580 to 1640 Spain and Portugal were joined in a royal union.

15 Among Grotius' followers see the Dutch jurist Theodorus Graswinckel (160o-1666): TIF Graswinckel, Maris liberi vindiciae adversus Petrum Baptistam Burgum Ligustici maritime dominii assertorem (Hagae Comitum, 1652); TIF Graswinckel, Maris liberi vindiciae adversus Guglielmum Welwodum Britannici maritime dominii assertorem (Hagae Comitum, 1652).

16 'Atqui ut Insulae in mari proxime adiacentes, sic \& mare ipsum ad centum usque millaria pro territorio districtuque illius cui proxime appropinquat, assignatur. Territorium porro omne Dominum habet aliquem oportet, vel, (quod idem valet) in dominio alicujus sit, necesse est: Mare ergo terrae proximum ejusdem terrae proximae Dominum agnoscere 
cannot be expressed in a predetermined distance from the shore, but is based on the needs of the coastal State, provided that other States are not affected. ${ }^{17}$

\section{$4 \quad$ The Cannon Shot Limit}

The theoretical battle between the freedom and sovereignty of the sea had a quite obvious outcome based on what occurred in reality. It was a matter of fact that all of the claims over the wider oceans and seas remained devoid of any concrete possibility of enforcement (other than on an ad hoc basis through the exercise of naval authority against foreign flagged ships). However, it was possible to enforce claims to regulate fishing activities or protect neutrality from acts of naval belligerency within a narrow belt of coastal waters.

In the last period of his life, Grotius remarked that what should be discussed was not the possibility to occupy marine space in itself, but how to distinguish the coastal waters, which are subject to occupation, from the rest of the sea, which is reserved for the regime of freedom: 'Puto non ut disputetur an mare in jus proprium cujusquam possit concedere, sed quanta cuique pars cessura sit'.18 Through a minor, but sensible, concession, Grotius elegantly won the battle against all the supporters of coastal State sovereignty over the sea, despite the many efforts that the latter deployed in their learned and sometimes redundant writings.

cogetur: pars etenim illa maris proxima, sic terrae proximae copulatur, \&, ut sic loquar, incorporatur, ut ne Principi Dominove illius terrae regnive, vel particulam, usumve alienare aut locare licet magis quam regnum ipsum regnique patrimonium. Ultra has maris partes terrae proximas, quicquid reliquum est, vastum videlicet immensumque aequor omnibus gentibus ad omnes usus indifferenter patere debere, extra omnem controversiam pono'. Welwod, De dominio above (n 11), 13 .

17 'Cercano i Giureconsulti quanta parte del Mare appartenga a ciascheduna Città: ed alcuni d'essi hanno detto cento miglia; ma parlando propriamente ella è tanto grande, quanto può ad operare a suo uso, senza ingiuria de' Vicini; perché una grande, e popolata Città sul Mare, la quale abbondi di siti terrestri, dove cavi il suo vitto, avrà pochi, che vogliano far il mestiere di Pescatore, e si valerà di poco Mare, dove una picciola Città con un poco di commodità in Terra attenderà a cavare il vitto dal Mare, e si valerà di gran parte d'esso; e non altrimente hanno voluto intendere i Giureconsulti de' cento miglia; ponendo un numero determinato per un incerto; cioè le Città sono Padrone di tanta parte di Mare, di quanta hanno bisogno di valersi senza ingiuria d'altri, se fossero ben cento miglia'. Sarpi, Opere, above (n 12), II, 346 .

18 Letter written by Grotius in 1637, in BL Meulenbroek, PC Molhuysen and PP Wikam (eds), Briefwisseling van Hugo Grotius (M Nijhoff, 1928) vol viII, 3 О3. 
At the beginning of the eighteenth century, the Dutch jurist Cornelis van Bynkershoek (1673-1743) gave a logical response to the pending question of the extent of coastal State sovereignty. ${ }^{19}$ If the decisive element is possession, that is the concrete exercise of State authority accompanied by the intention to possess, the limit of sovereignty must be found in the extent of waters that the coastal State can effectively possess. The effectiveness of possession can be granted by the continuous navigation by a fleet within a certain extent of waters. But - and here is the most characteristic aspect of Bynkershoek's theory - the control of the sea from the sea could be replaced by the control of the sea from land. It follows that the limit of the sovereignty of the coastal State is the range of space that can be covered by the weapons placed on land (the so-called cannon shot rule). ${ }^{20}$ The underlying idea, which is still today retained in international law of the sea, is that title over coastal waters has an accessory character with respect to title established on land.

Quare omnino videtur rectius, eo potestatem terrae extendi, quousque tormenta exploduntur, eatenus quippe cum imperare, tum possidere videmur. Loquor autem de his temporibus, quibus illis machinis utimur: alioquin generaliter dicendum esset, potestatem terrae finiri, ubi finitur armorum vis; etenim haec, ut diximus, possessionem tuetur. ${ }^{21}$

It is evident that the vast ocean, which could never be possessed by any fleets or weapons placed on the coast, is and must remain free:

Hunc [= vastum Oceanum] non occupari, certe possideri non posse res est oppido manifesta: omnes quippe omnium principum naves ei possidendo vix ac ne vix quidem suffecerint. ${ }^{22}$

After Bynkershoek, most of the authors considered the cannon shot rule as an acquired custom. For example, the Swiss lawyer Emmerich de Vattel (17141767) wrote as follows:

19 C van Bynkershoek, De dominio maris dissertatio (Lugduni Batavorum, 1744) (published for the first time in 1702).

20 It seems that the cannon shot rule was evoked for the first time in international practice by an embassy sent in 1610 to England by the United Provinces of the Netherlands to discuss the question of fisheries after the 1609 proclamation by James I.

21 Bynkershoek, above (n 19) 364. See WL Walker, 'Territorial Waters: The Cannon Shot Rule' (1945) 22 British Yearbook of International Law 210-231. Ibid 391. 
Aujourd'hui tout l'espace de mer, qui est à la portée du canon le long des côtes, est regardé comme faisant partie du territoire; \& pour cette raison, un vaisseau pris sous le canon d'une forteresse neutre, n'est pas de bonne prise. $^{23}$

During the eighteenth century, in State practice the cannon shot rule was felt especially appropriate for defining the limit within which acts of naval belligerency by foreign powers were not permitted. This is the case of a treaty signed on 14 May 1762 by Algeria and Great Britain:

It is also agreed, that if any ships or vessels of Christian nations, in enmity with the King of Great Britain, \&c. shall, at any time hereafter, be met with or found upon the coast of the Kingdom of Algier, either at anchor or otherwise, and not within the reach of cannon shot from the shore, that it shall and may be lawful for any of His Britannic Majesty's ships or vessels of war, or any English privateers, or letters of marque, to take and seize as prizes, any such ships or vessels so met with or found, as aforesaid. $(\text { Article } 2)^{24}$

Although attractive from a logical point of view, the cannon shot rule presented some evident shortcomings if considered in a practical perspective. Was the limit subject to change as a consequence of the progress of ordnance? And (an even more difficult question) was the limit to be considered in a concrete sense, with the result that the coastal State was not entitled to exercise any rights along the shores where no artillery was in place? Or was the limit to be considered in an abstract sense, as granting to any coastal State rights over the extent of waters which could potentially be controlled by a cannon, even if no artillery was in place? The answers were not at all clear.

An innovative proposal, which aimed at a useful simplification of a complex question, came in 1782 from the Neapolitan scholar Ferdinando Galiani $(1728-1787)$. He proposed the introduction of the limit of three nautical miles

23 E de Vattel, Le droit des gens, ou principes de la loi naturelle, appliqués à la conduite \& aux affaires des nations et des souverains, vol I (Londres, 1758) 424.

24 Articles of Peace and Commerce between Great Britain and Algiers, 14 May 1762, 42 CTS 159 . 
for the territorial sea, this being the furthest distance which could be reached by a cannon shot:

Mi parrebbe peraltro ragionevole, che senza attendere a vedere se in atto tenga il Sovrano del territorio costrutta taluna torre o batteria, e di qual calibro di cannoni la tenga montata, si determinasse fissamente, e da per tutto la distanza di tre miglia dalla terra, come quella, che sicuramente è la maggiore ove colla forza della polvere finora conosciuta si possa spingere una palla, o una bomba. ${ }^{25}$

Galiani's suggestion was the best way to eliminate all the efforts to determine whether and where artilleries were in place and engage in calculations about their range. It is much easier to measure a fixed distance from the coast and draw the corresponding limit on a map. After Galiani, geometry was ready to enter the international law of the sea and play the role of simplification of problems. Indeed, the formation of the concept of territorial sea ${ }^{26}$ and the measuring of its width in terms of nautical miles from the coast were both the end of a long-lasting dispute on sovereignty or freedom and the beginning of new way of understanding the law of the sea, as mostly based on geometry.

During the nineteenth century, the trend towards geometric stability, that is the establishment of a narrow belt of coastal waters gained widespread diffusion in international practice, either for the purpose of neutrality in time of war or for general purposes. Its width comprised somewhere between three nautical miles, as claimed by the United States and Great Britain, and twelve nautical miles, as claimed by some other coastal States.

Once accepted that a State is entitled to exercise its sovereignty over a belt of coastal waters, another question of 'frontier' comes to existence, that is, how to

25 F Galiani, De' doveri dei principi neutrali verso i principi guerreggianti, e di questi verso $i$ neutrali, libri due (1782) 422.

26 Galiani used the expression 'territorial sea' ('mare territoriale' in Italian): 'Finalmente è anche cosa ricevutissima, che del mare aperto quell'orlo, che bagna il lido della terra, appartiene, si riguarda come incorporato col territorio, e fa parte di esso. Han variato però ne' diversi secoli le opinioni e gli usi sulla estensione di cotesto mare territoriale'. Ibid 420. On the three-mile limit see HS Kent, 'The Historical Origins of the Three-Time Limit' (1954) 48 American Journal of International Law 537-553. 
determine the boundary between the waters subject to the sovereignty of two adjacent or opposed States, where such claims potentially overlap according to the foregoing limits. Questions of delimitation of marine waters are particularly frequent today, due to the fact that additional coastal zones adjacent to the territorial sea can be established. ${ }^{27}$ Presently, negotiators or courts can apply geometry in a quite sophisticated way, elaborating on the drawing of equidistance lines and on circumstances in which departures from such lines can be made.

It is interesting to remark here that the first time ${ }^{28}$ when the subject of maritime delimitation was envisaged was in a book published in 1760 by the French jurist René-Josué Valin (1695-1765). He proposed to adopt the sounding line as the limit of a coastal State's sovereignty and to follow the median line where there was a need to determine the boundary between opposed coastal States:

[I]l auroit été mieux peut-être de juger du domaine sur la mer voisine de la côte par la sonde, \& d'en aligner les bornes précisément à l'endroit où la sonde auroit cessé de prendre fond; de manière que, hors de la portée de la sonde, la mer eût été reconnue libre pour la navigation et la pêche, comme ne pouvant être du domaine de personne.

Et s'il fût arrivé qu'entre deux états il y eût un bras de mer où l'on pût prendre fond par-tout, alors le milieu auroit servi de point de partage. ${ }^{29}$

The customary acceptance of a narrow belt of coastal waters did not exclude some sporadic, but significant, instances of extravagant claims when they were deemed useful to meet specific needs. Such claims were advanced by two naval powers, Great Britain and the United States, which were mostly attached to the narrowest limit of three nautical miles.

On 9 March 1811 Great Britain adopted a regulation for the protection of His Majesty's pearl banks in Ceylon:

Whereas there is reason to suspect that depredations are committed in the pearl banks of this Island by boats and other vessels frequenting

27 See present chapter, sections 8 and 9.

28 To the best of the current author's knowledge.

29 R-J Valin, Nouveau commentaire sur l'ordonnance de la marine du mois d'août 1681 (La Rochelle, 1776) vol II, 687 (published for the first time in 176o). 
those places in the calm season without any necessity or lawful cause for being in that situation:

For the protection of His Majesty's property and revenue, His Excellency the Governor in Council is pleased hereby to enact and declare:

That if any boat or other vessel shall hereafter, between the 1oth of January and the end of April, or between the 1st of October and the end of November in any year, be found within the limits of the pearl banks, as described in the schedule annexed, anchoring or hovering and not proceeding to her proper destination as wind and weather may permit, it shall be lawful for any person or persons holding a commission or warrant from His Excellency the Governor for the purposes of this Regulation to enter and seize such boat or other vessel, and carry the same to some convenient port or place in this island for prosecution....

Schedule referred to: Vessels navigating the inner or alongshore passage are not to hover or anchor in deeper than four fathoms water. Vessels navigating the outer passage are not to hover or anchor within twelve fathoms water. ${ }^{30}$

The special features of pearl fishing, which was conducted by diving, meant that the regulations referred to the bathymetric limit of four fathoms (one fathom equal to 1.83 metres). Due to the shallowness of the waters in the area in question, this meant that control by the British authorities extended as far as 20 nautical miles from the coast. The regulations adopted for Ceylon in 1811 are the antecedent of the measures subsequently enacted by some countries with regard to the exploitation of the so called sedentary species (such as chanks, bêches-de-mer, corals, shells, oysters, sponges) located beyond the external limit of the territorial sea.

Another exceptional claim was advanced over what can be called the 'Napoleonic sea'. It was established by Great Britain on 11 April 1816 in order to restrict national and foreign navigation within eight leagues (corresponding to 24 nautical miles) around the island of Saint Helena for the period when the former French emperor was detained there:

[A]nd if any Ship, Vessel or Boat, not belonging in the whole or in part to any Person or Persons, the Subject or Subjects of, or owing allegiance to His Majesty, his Heirs and Successors, shall repair to, or trade or touch,

30 Text in Bering Sea Tribunal of Arbitration, Proceedings of the Tribunal of Arbitration (Washington, GPO, 1895) vol II, 461. See CJB Hurst, 'Whose Is the Bed of the Sea?' (192324) 4 British Yearbook of International Law 34-43. 
at the said Island of Saint Helena, or shall be found hovering within 8 leagues of the Coast thereof, and shall not depart from the said Island or the Coast thereof, when and so soon as the master or other person having the charge and command thereof, shall be ordered to do so by the Governor or Lieutenant Governor of the said Island for the time being, or by the Commander of His Majesty's Naval or Military Force stationed at or off the said Island for the time being (unless in case of unavoidable necessity, or distress of weather) such Ship or Vessel shall be deemed forfeited, and shall and may be seized and detained and prosecuted in the same manner as in herein-before enacted as to Ships, Vessels, or Boats, of or belonging to any Subject or Subjects of His Majesty. ${ }^{31}$

The United States, which already in 1799 had established a 12-mile customs protection zone, enacted on 5 August 1935 the Anti-Smuggling Act, occasionally extending the customs enforcement to 62 miles from the coast:

Whenever the President finds and declares that at any place or within any area of the high seas adjacent to but outside customs waters any vessel or vessels hover or are being kept off the coast of the United States and that, by virtue of the presence of any such vessel or vessels at such place or within such area, the unlawful introduction or removal into or from the United States of any merchandise or person is being or may be occasioned, promoted, or threatened, the place or area so found and declared shall constitute a customs-enforcement area for the purposes of this chapter....

No customs-enforcement area shall include any waters more than 100 nautical miles from the place or immediate area where the President declares such vessel or vessels are hovering or are being kept and, notwithstanding the foregoing provision, shall not include any waters more than fifty nautical miles outwards from the outer limit of customs waters. $^{32}$

By their very existence, these extravagant claims prove that the elements of subjectivism and dynamic instability were never absent from the picture of international law of the sea. The idea of a single frontier did not appear always

$31 \quad$ Text in British and Foreign State Papers, vol 3, 364.

32 Text in United Nations, Laws and Regulations on the Régime of the High Seas (United Nations, 1951) vol I, 107. 
appropriate and, where different interests were involved, the establishment of two frontiers was seen as a preferable solution.

After World War II, the evolution of international law of the sea was greatly influenced by unilateral measures adopted by coastal States. What could be considered as isolated and extravagant measures progressively became the rule.

The first of these measures is the Presidential Proclamation concerning the policy of the United States with respect to the natural resources of the subsoil and seabed of the continental shelf, adopted on 28 September 1945 (the so-called Truman Proclamation). ${ }^{33}$ The proclamation was limited to the natural resources of the continental shelf, described in an official press release as 'submerged land which is contiguous to the continent and which is covered by no more than 100 fathoms (6oo feet) of water', and did not affect the high seas character of the superjacent waters, in particular freedom of navigation therein by all States. By establishing a special zone of seabed adjacent to the territorial sea and subject to the jurisdiction of the coastal State, the Truman Proclamation radically altered the balance between sovereignty and freedom of the sea that had been previously set in a generally accepted way. It was the starting point for a process of fragmentation of coastal zones and, consequently, of the frontier between 'sovereignty' and 'freedom', depending on the interests involved.

From the legal point of view, the United States was fully aware of the innovative nature of a claim which was based on the economic need to exploit the valuable deposits of mineral resources, mostly oil, located in the continental shelf, following the rapid development of technical knowledge and equipment. ${ }^{34}$ In the preamble of the proclamation, the United States put forward that it was 'reasonable and just' to claim jurisdiction beyond the limit of the territorial sea and that the coastal State was best placed to adopt measures for the conservation and utilization of the mineral resources of the continental shelf.

Several coastal States followed the example of the United States and no substantial objection was made against this practice. ${ }^{35}$ The 1958 Geneva

Ibid 38. See H Lauterpacht, 'Sovereignty over Submarine Areas' (1950) 27 British Yearbook of International Law 376-433.

34 See AL Hollick, U.S. Foreign Policy and the Law of the Sea (Princeton University Press, 1981) 18.

For the relevant legislation, see United Nations, above (n 32 ). 
Conference, convened by the United Nations for the codification of international law of the sea, devoted one of the four conventions that it adopted to the regime of the continental shelf. ${ }^{36}$ The coastal State is granted sovereign rights for the purpose of exploring the continental shelf and exploiting its natural resources. These rights do not depend on occupation or on any express proclamation and are exclusive 'in the sense that if the coastal State does not explore the continental shelf or exploit its natural resources, no one may undertake these activities, or make a claim to the continental shelf, without the express consent of the coastal State. ${ }^{37}$ In a very short time, the rights of the coastal State over the continental shelf acquired an inherent character, even though they originated from the unilateral claims made by some States.

Only a few years after the Truman Proclamation a number of Latin American countries took similar action as regards the living resources existing in their coastal waters within a 200-mile belt. ${ }^{38}$ The measures in question were based on the same purpose as the Truman Proclamation, namely to go beyond the limit of the territorial sea with the aim of avoiding a 'freedom-of-exploitation' or a 'first-come-first-served' regime. The only difference was that they related to the living resources of the superjacent waters, rather than to the mineral resources of the seabed.

The first precedent in the 200-mile direction was a declaration by Chile of 23 June 1947, followed by a decree of Peru of 1 August 1947, a law-decree of Costa Rica of 27 July 1948, the Constitution of El Salvador of 7 September 1950, and a decree of Honduras of 17 January 1951. The manifesto of the new trend was the declaration on the maritime zone (zona maritima), jointly adopted by Chile, Ecuador and Peru in Santiago on 18 August $1952 .{ }^{39}$ The three States proclaimed 'as a principle of their international maritime policy that each of them possesses exclusive sovereignty and jurisdiction over the area of sea adjacent to the coast of its own country and extending not less than 200 nautical miles from the said coast'.

Unlike the Truman Proclamation, the measures adopted by Latin American countries met with the opposition of the major maritime powers. They considered such measures as unreasonable claims, lacking any pertinent precedents.

$36 \quad 195^{8}$ Convention on the Continental Shelf, 499 UNTS 311.

37 Ibid Art 2(2).

38 See BBL Auguste, The Continental Shelf: The Practice and Policy of the Latin American States with Special Reference to Chile, Ecuador and Peru (Minard, 196o); A Szekely, Latin America and the Development of the Law of the Sea (Ocean Publications, 1976).

39 Text (English translation) in United Nations, Laws and Regulations on the Régime of the Territorial Sea (New York, 1957) 723. 
To respond to these arguments, Latin-American jurists advanced a number of extra-legal arguments. ${ }^{40}$ For instance, they stressed that the geological continental shelf along the Pacific shore of South America is narrow or non-existent. The coastal States in the area were consequently entitled to a 200-mile zone of water, corresponding to the influence of the cold Humboldt stream which determined an extraordinary abundance of living resources, as compensation for the rights they would have enjoyed over mineral resources if a normal continental shelf had existed. This argument has a convincing basis in logic and equity. Why should the trend to go beyond a narrow limit of the territorial sea be in conformity with international law if applied to the mineral resources of the seabed, but illegitimate if related to the living resources of the superjacent waters?

Other arguments were based on economic and political reasons. As stated in the Santiago declaration, governments are bound to ensure their peoples access to necessary food resources and to supply them with the means of developing their economy. Moreover, coastal States are entitled to extend the limits of their maritime sovereignty, as they are better placed than long-distance fishing States (this echoes mutatis mutandis, the rationale put forward by the United States for extending its rights over the continental shelf). The fishing fleets of the latter can deplete the living resources of a high seas area located beyond the narrow limit of the territorial sea and then move on to deplete the resources of another area. On the contrary, developing States have a stronger interest in 'eating' or 'selling' the living resources located along their coasts. They can use these resources to fill the food gaps and promote new economic activities by obtaining financial benefits from licenses paid by foreign fishermen. This would also allow coastal States to progressively increase their own fishing capacity and better provide to their economic development.

Unlike the Truman Proclamation, for a certain number of years the 200mile zones established by several Latin American countries were strongly opposed by the major maritime powers. They were considered rather like folkloristic measures and were quoted as examples of abnormal claims. The four conventions of codification of international law of the sea that were adopted in Geneva in $1958^{41}$ did not at all reflect the measures adopted by the Latin American countries.

40 See A Ulloa, 'El régimen jurídico del mar' (1957) Revista Peruana de Derecho Internacional 69 .

41 Namely the Convention on the Territorial Sea and the Contiguous Zone, the Convention on the High Seas, the Convention on Fishing and Conservation of the Living Resources of the High Seas and the Convention on the Continental Shelf. A Second United Nations Conference on the Law of the Sea was convened in 196o to examine the questions of the 
However, after decolonization, the reasons for the enlargement of coastal State jurisdiction were put forward also by several newly independent African countries which shared the need for economic development. They unilaterally established coastal zones ranging from 30 to 200 nautical miles. The conclusions of the regional seminar of African States on the law of the sea, held in Yaoundé in $1972,{ }^{42}$ called for the establishment of an 'economic zone', where the African States were entitled to 'an exclusive jurisdiction for the purpose of controlling regulation and national exploitation of the living resources of the sea and their reservation for the primary benefit of their peoples and their respective economies, and for the purpose of prevention and control of pollution'.

Particularly interesting is the denunciation by Senegal in 1971 of the Geneva 1958 conventions on the territorial sea and on high seas fishing to which it had acceded ten years before. In a letter addressed on 3 June 1971 to the SecretaryGeneral of the United Nations, as depositary of the two conventions, the President of Senegal, Léopold Senghor, clearly explained the political and economic reasons that made the traditional regime of fishing unacceptable for developing countries:

La situation des Etats côtiers de l'Afrique occidentale est inextricable, car, aujourd'hui, ils n'ont pas encore les navires et les équipements nécessaires pour procéder à des captures sur une grande échelle, comme le font les pêcheurs des pays industrialisés, et demain, lorsqu'ils auront ces navires et ces équipements, les zones de pêche auront été épuisées par les activités des pays industrialisés. ... Les Etats riches, industrialisés, épousent toujours des thèses qui restreignent l'étendue de la mer territoriale et font de la haute mer un domaine où la supériorité de leurs moyens financiers et techniques leur permettent de jouir, d'une façon presque exclusive, des richesses des eaux au large des côtes sénégalaises. Le régime de la liberté profite aux plus riches, aux mieux équipés, et non aux sous-développés, aux plus pauvres. ${ }^{43}$

breadth of the territorial sea and the limits of fishing zones that had not been solved by the 1958 conventions. It did not succeed in gathering sufficient acceptance on solutions to these thorny questions.

Text in United Nations, National Legislation and Treaties relating to the Law of the Sea (New York, 1974) 6o1.

43 Excerpts from the letter of President Senghor are reproduced in D Bardonnet, 'La dénonciation par le Gouvernement sénégalais de la Convention sur la mer territoriale et la zone contiguë et de la Convention sur la pêche et la conservation des ressources biologiques de la haute mer, en date du 29 avril $195^{8}$ à Genève' (1972) 18 Annuaire Français de Droit International $123-180$. 
Here it is clearly stated that the regime of freedom of the sea serves to profit the richest. If this simple sentence sounds strange it is only for psychological reasons, as the word 'freedom' currently has a positive meaning, being associated with fundamental human rights. But in the field of law of the sea 'freedom' has acquired a different meaning and President Senghor's statement is a sign of how, in the second half of the twentieth century, the picture and the problems had changed since the period when Grotius laid the foundations of law of the sea. The logic of the old frontier should be replaced by a new logic and a new frontier.

In the same period the trend towards a 'creeping jurisdiction' beyond the 12-mile limit was followed by Canada, which was confronted with a new concern. In 1970, Canada, by the Arctic Waters Pollution Prevention Act, adopted measures for the regulation of navigation and the prevention of pollution from vessels within a 10o-mile zone in Arctic waters, between $60^{\circ}$ latitude North and $141^{\circ}$ longitude West. ${ }^{44}$ Canada was concerned about the environmental risk of a project planned by United States companies to develop a route of navigation through the Northwest Passage and within the islands of the Canadian Arctic Archipelago to be used by ice-strengthened supertankers carrying oil extracted in Alaska. The traditional rules of the law of the sea on freedom of navigation on the high seas and innocent passage in the territorial sea and international straits could have applied to the project. The lack of precedents drove Canada to play the role of promoting the evolution of legal rules in a 'first-time' case, that is a situation that had never happened before, where established custom could not meet the new needs of the international community in general. Why Canada was urged to resort to unilateral action was very frankly acknowledged in an interview granted by in 1970 by the Prime Minister, Pierre Trudeau:

The way international law exists now, it is definitely biased in favour of shipping in the high seas and in the various parts of the globe. And in the past this has probably been to the benefit of the states of the world because there has been, because of this bias in international law, a great deal of development of commerce in all parts of the globe. ... And this was fine in the past, but now with the advance of technology and the importance which is coming forth to us in all parts of the world - of not only thinking of commerce, but also of quality of life - we're saying international law has not developed in this direction.... 
Where no law exists, or where law is clearly insufficient, there is no international common law applying to the Arctic seas, we're saying somebody has to preserve this area for mankind until the international law develops. And we are prepared to help it develop by taking steps on our own and eventually, if there is a conference of nations, concerned with the Arctic, we will of course be a very active member in such a conference and try to establish an international regime. But, in the meantime, we had to act now. ${ }^{45}$

These statements are notable for several reasons. They provide an example of how international customary rules can develop as a result of unilateral action by interested States. They show how, following the advance of technology in shipping, the traditional regime of freedom of navigation becomes inadequate to meet the concerns of not only a single coastal State, but the international community in general. They anticipate the crucial question of how to reconcile the interests of navigation and shipping with the need to protect the marine and coastal environment. As regards the trend to go beyond the 12-mile limit, a new kind of unilateralism, coming from a State concerned about the preservation of the quality of the environment, was to be added to the previous unilateralism of countries which wanted to 'eat' or 'sell' the fish of their coastal waters.

A Third United Nations Conference on the Law of the Sea, whose preparation began in 1968, was convened in 1973. It produced the 1982 United Nations Convention on the Law of the Sea (LOSC). ${ }^{46}$ The mere fact that a few years after the adoption of the 1958 Geneva Conventions, the machinery for a new conference of codification started again shows how quickly the evolutionary trends affected the results achieved in Geneva, including the frontiers established under the Geneva Conventions.

45 Documents concerning Canadian legislation on Arctic pollution and territorial sea and fishing zones are reproduced in (1970) 9(3) International Legal Materials 6oo. See L Henkin, 'Arctic Anti-Pollution: Does Canada Make or Break International Law?' (1971) 65 American Journal of International Law 131-136.

461833 UNTS 3 (LOSC). On this treaty see, inter alia, a volume edited by the friend and scholar to whom this collection of essays is dedicated: D Freestone (ed), The 1982 Law of the Sea Convention at 3o: Successes, Challenges and New Agendas (Brill/Nijhoff, 2013). 
During the negotiations for the LOSC, the trend towards a 200-nautical mile maritime zone, now called the exclusive economic zone, gained widespread support and became acceptable, under certain conditions, for all States including developed countries and the major naval powers. Part v of the LosC codifies the exclusive economic zone as a sui generis zone where the coastal State enjoys certain sovereign rights and jurisdictions and the other States retain certain high seas freedoms. In reading the list of the rights granted to the coastal State, the contribution of the United States' practice (sovereign rights for the purpose of exploiting the non-living resources of the seabed), the Latin American practice (sovereign rights for the purpose of exploiting the living resources of the waters) and the Canadian practice (jurisdiction with regard to the protection and preservation of the marine environment) can easily be recognized. However, as it clearly results from the relevant provisions of the LOSC, the exclusive economic zone is something different from a territorial sea and the rights granted to the coastal State do not in principle encroach upon the traditional freedom of navigation.

Today the 2oo-nautical mile exclusive economic zone belongs to the field of customary international law. Such a zone has been established by the great majority of coastal States. The trend to go beyond the territorial sea has continued and consolidated its course and has resulted in the establishment of new frontiers.

The concept of the common heritage of mankind is another basic innovation, with respect to the previous Geneva codification, that was included in the LOSC. This concept presupposes a third kind of regime which is different from both the concepts of sovereignty and freedom.

The idea of the common heritage of mankind was launched in a memorable speech made at the United Nations General Assembly on 1 November 1967 by the representative of Malta, Arvid Pardo. The practical opportunity for proposing a completely new regime was given by the technological developments which were expected to lead in a relatively short time to the commercial exploitation of polymetallic nodules which lie on or just below the surface of the deep seabed and which contain manganese, nickel, cobalt and copper. The application of the existing regime of freedom of the high seas was likely to lead to a rush towards the appropriation of these economically and strategically valuable minerals on 'first-come-first-served' basis. Another, equally undesirable, possibility was a series of competitive extensions of the limits of national 
jurisdiction on the seabed by coastal States because the then limit of the continental shelf was set according to the test of exploitability under Article 1 of the Continental Shelf Convention 1958. According to Mr. Pardo's speech, the consequences of this possible scenario would have been very grave and would have ranged from political tension to economic injustice and risks of pollution:

The known resources of the seabed and of the ocean floor are far greater than the resources known to exist on dry land. The seabed and ocean floor are also of vital and increasing strategic importance. Present and clearly foreseeable technology also permits their effective exploration for military or economic purposes. Some countries may therefore be tempted to use their technical competence to achieve near-unbreakable world dominance through predominant control over the seabed and the ocean floor. This, even more than the search for wealth, will impel countries with the requisite technical competence competitively to extend their jurisdiction over selected areas of the ocean floor. The process has already started and will lead to a competitive scramble for sovereign rights over the land underlying the world's seas and oceans, surpassing in magnitude and in its implications last century's colonial scramble for territory in Asia and Africa. The consequences will be very grave: at the very least a dramatic escalation of the arms race and sharply increasing world tensions, also caused by the intolerable injustice that would reserve the plurality of the world's resources for the exclusive benefit of less than a handful of nations. The strong would get stronger, the rich richer, and among the rich themselves there would arise an increasing and insuperable differentiation between two or three and the remainder. Between the very few dominant powers, suspicions and tensions would reach unprecedented levels. Traditional activities on the high seas would be curtailed and, at the same time, the world would face the growing danger of permanent damage to the marine environment through radioactive and other pollution: this is a virtually inevitable consequence of the present situation. ${ }^{47}$

The basic elements of the new regime of common heritage of mankind, applying to the seabed beyond the limits of national jurisdiction (called 'the Area' in the LOSC) and its mineral resources, are the prohibition of national appropriation, the designation of the Area for peaceful purposes, the use of the Area and 
its resources for the benefit of mankind as a whole with particular consideration for the interests and needs of developing countries, as well as the establishment of an international organization entitled to act on behalf of mankind in the exercise of rights over the resources.

All the elements mentioned above can be found in Part XI of the $\mathrm{LOSC}^{48}$ and represent the most innovative part of the 1982 codification of law of the sea. The Area and its resources are the common heritage of mankind (Article 136). No State can claim or exercise sovereignty over any part of the Area, nor can any State or natural or juridical person appropriate any part thereof (Article 137(1)). The Area is open to use exclusively for peaceful purposes (Article 141). All rights over the resources of the Area are vested in mankind as a whole, on whose behalf acts the International SeaBed Authority (ISA), the international organization created by the LOSC (Article 137(2)). Activities in the Area are carried out for the benefit of mankind as a whole, irrespective of the geographical location of States, whether coastal or land-locked, and taking into particular consideration the interests and needs of developing States (Article 140 (1)). The ISA provides for the equitable sharing of financial and other economic benefits derived from activities in the Area through an appropriate mechanism (Article $140(2))$.

For the first time in the historical development of international law a regime based on the management of resources by an international organization was included in a treaty of codification. The LOSC regime is a major departure from the usual trend of finding a 'frontier' in the everlasting conflict between the opposing schemes of freedom or sovereignty. Without eliminating the traditional notions of freedom and sovereignty for the remaining resources and the remaining marine spaces, the common heritage of mankind is a third conceptual option, a sort of tertium genus, which applies to the mineral resources located in a specific marine space.

At the basis of international law of the sea is the principle of freedom of the sea, which is mostly linked to interest in navigation. However, when the principle

48 Although Part XI has been subsequently modified by the 1994 Agreement relating to the Implementation of Part XI of the LOSC, which is annexed to Resolution 48/263, adopted by the UN General Assembly on 17 August 1994, the spirit of the LOSC has not been betrayed and the principle of common heritage of mankind remains a major source of inspiration. 
of freedom of the sea was elaborated, nobody had in mind the problems posed by supertankers and nuclear-propelled vessels, fishing with destructive nets, off-shore drilling, mining for polymetallic nodules and many other activities which take place in the marine environment today. This obvious consideration leads to an equally obvious consequence. We cannot today evoke the same concepts that Grotius used and give them the same intellectual and legal strength that Grotius gave them.

The needs of navigation are still important elements to be taken into consideration. But they have to be balanced with other interests, in particular those which have a collective character, such as the protection of the marine environment and the sustainable exploitation of marine resources, as they concern the international community as a whole. Far from being an immutable theological dogma, the principle of freedom of the sea is to be understood not in an abstract way, ${ }^{49}$ but in the light of the peculiar circumstances under which it should apply.

Not only does the principle of freedom of the sea have a relative character, it has also undergone a process of progressive weakening. As a result of the need to subject new interests and activities to specific regulation, the weakening of the principle of freedom of the sea has been the main trend in the evolution of international law of the sea. This process increased at an irresistible pace in the second half of the twentieth century. The spaces to which new regimes became applicable, such as the seabed beyond the territorial sea, the waters within 200 nautical miles from the coast and the seabed beyond the limit of national jurisdiction, were all previously subject to the high seas regime. The successful outcome of innovative legal concepts, such as the continental shelf, the exclusive economic zone and the common heritage of mankind, witness how a 'first come, first served' regime, based on exclusive flag State jurisdiction, was considered to be inadequate to regulate the exploitation of natural resources (oil, fish, polymetallic nodules) and the protection of the marine environment. All the above-mentioned innovations are confirmed by the LOSC or embodied in the LOSC.

There is no doubt that the LOSC is a cornerstone in the process for the codification of international law. It has been rightly described as a 'constitution for oceans', 'a monumental achievement in the international community', 'the first comprehensive treaty dealing with practically every aspect of the uses and resources of the seas and the oceans', as well as an instrument that 'has

49 Besides, to understand the principle of freedom of the sea in an abstract way would not conform to the profound doctrine, the lucid spirit and the practical intelligence of Hugo Grotius. 
successfully accommodated the competing interests of all nations. ${ }^{50}$ However, the assumption that everything that occurs in the seas must necessarily fall under the scope of the LOSC is far from convincing.

A first remark in this regard is that there are some evident gaps in the LOSC itself. The States involved in the negotiations for this convention were not willing or capable to address and settle a few thorny questions that were deliberately left vague and subject to development through other processes. In this case, the gaps could be filled by resorting to provisions of customary international law (regulation through customary international law). ${ }^{51}$ It may also happen that some LOSC provisions make use of general terms that lack sufficient precision. ${ }^{52}$ Where different understandings of the relevant LOSC provisions are in principle admissible, State practice may be important in making one interpretation prevail over another (regulation through LOSC interpretation). ${ }^{53}$

A second, and even more obvious, remark is that, while it provides a solid legal regime for many matters, it would be illusory to think that the LOSC is the end of legal regulation in the field of law of the sea. Being itself a product of time, the LOSC cannot stop the passing of time. Unexpected problems may arise and new activities can be carried out that require specific rules, including perhaps some departures from the Losc provisions. In two cases additions and changes with respect to the original LosC regime have been integrated into the regime itself through the adoption of so-called implementation agreements (regulation through integration into the $\operatorname{LOSC}^{54}$ ). In another case where the LOSC regime was clearly unsatisfactory, a new instrument of universal scope has been drafted to avoid the risk of undesirable consequences (regulation in another context). ${ }^{55}$ This happens very seldom, but cannot be excluded altogether.

$50 \quad$ See T Koh, 'A Constitution for the Oceans' in United Nations, The Law of the Sea: Official Text of the United Nations Convention on the Law of the Sea with Annexes and Index (United Nations, 1983) xxiii.

$5^{1}$ This is the case of the rules applying to maritime boundaries.

$5^{2}$ This is the case of the rules applying to the baseline of the territorial sea or to islands.

53 See J Barrett and R Barnes (eds), The United Nations Convention on the Law of the Sea: A Living Instrument (BIICL, 2016).

54 This is the case of the already mentioned 1994 Agreement Relating to the Implementation of Part XI of the LOSC, above (n 48), and the 1995 Agreement for the Implementation of the provisions of the United Nations Convention on the Law of the Sea of 10 December 1982 relating to the conservation and management of straddling fish stocks and highly migratory fish stocks, 2167 UNTS 3 .

55 This is the case of the 2001 Convention on the Protection of the Underwater Cultural Heritage, 2256 UNTS 1, adopted within the framework of the United Nations Educational, Scientific and Cultural Organization (UneSCo). 
Recent meetings and negotiations at the United Nations show that there is a field where substantive developments with respect to the present law of the sea regime may occur. On 19 June 2015, the United Nations General Assembly adopted by consensus Resolution 69/292, relating to the development of an international legally-binding instrument under the LOSC on the conservation and sustainable use of marine biodiversity beyond national jurisdiction. A Preparatory Committee (Prepcom) was established with the mandate to make substantive recommendations to the General Assembly on the elements of a draft text of such instrument. The Prepcom negotiations addressed four main topics intended as a 'package', in the sense that none of them can be separated from the others, namely 'marine genetic resources, including questions on the sharing of benefits', 'measures such as area-based management tools, including marine protected areas', 'environmental impact assessments' and 'capacity building and transfer of marine technology'.

Following the Prepcom recommendations, the General Assembly, by Resolution 72/249 of 24 December 2017, decided to convene an intergovernmental conference to elaborate the text of an international legally binding instrument under the LOSC on the conservation and sustainable use of marine biological diversity of areas beyond national jurisdiction. The negotiations started in September 2018. Several elements generated consensus among most delegations attending the meetings. However, on other elements there was divergence of views.

Among the main topics, the question of marine genetic resources presents a number of political and legal challenges that probably make it the most difficult aspect of the negotiation. ${ }^{56}$ Differences persist as regards a number of components of the future regime, starting from the fundamental choice on whether it should be based on the principle of freedom of the high seas or on the principle of common heritage of mankind. The prospects of actual mineral exploitation in the Area under the regime of common heritage of mankind

56 On the many questions to be addressed by the negotiations, see D Freestone, D Johnson, J Ardron, KK Morrison and S Unger, 'Can Existing Institutions Protect Biodiversity in Areas beyond National Jurisdiction? Experiences from Two On-going Processes' (2014) 49 Marine Policy 167-175; R Long and M Chaves 'Anatomy of a New International Instrument for Marine Biodiversity beyond National Jurisdiction: First Impressions of the Preparatory Process' (2015) 6 Environmental Liability 213-229; R Barnes 'The Proposed LOSC Implementation Agreement on Areas Beyond National Jurisdiction and Its Impact on International Fisheries Law' (2016) 31 International Journal of Marine and Coastal Law 583-619; T Scovazzi, The Negotiations for a Binding Instrument on the Conservation and Sustainable Use of Marine Biological Diversity beyond National Jurisdiction' (2016) 70 Marine Policy 188-191. 
remain uncertain, as some factors have a negative impact on their future commercial exploitation. They include the great depths at which deposits occur, the high costs involved in research and development of mining technology and the fact that, under current economic conditions, deep seabed mining remains uncompetitive if compared to land-based mining. In the meantime, the exploitation of genetic resources found beyond the limits of national jurisdiction has become a commercially promising activity. The deep seabed is not a desert, despite extreme conditions of temperature, complete darkness and high pressure. It is the habitat of diverse forms of life associated with typical features of the deep seabed, such as hydrothermal vents, cold water seeps, seamounts or deep-water coral reefs. In particular, hydrothermal vents support biological communities that present unique genetic characteristics, including the ability to survive extreme temperatures (thermophiles and hyperthermophiles), high pressure (barophiles) and other difficult conditions (extremophiles). So far, only few States and private entities have at their disposal the financial means and sophisticated technologies required to reach the deep seabed and take samples of organisms found there, in order to isolate in laboratories the genetic materials deriving from them. The result could be the development and patenting of commercially valuable products. The legal problems arising from this kind of activities are due to the fact that neither the LOSC, nor the 1992 Convention on Biological Diversity provide any specific regulatory framework for marine genetic resources beyond national jurisdiction.

In this regard, several States, especially within the group of developing countries, take the position that the LOsC principle of common heritage of mankind applies also to marine genetic resources and that the mandate of the ISA should cover also such resources. Other States, in particular some developed countries, rely on the principle of freedom of the high seas, which would imply freedom of access to, and unrestricted exploitation of, genetic resources. It seems that both the conflicting views follow from the frequently repeated assumption that the LOSC is the legal framework for all activities taking place in marine spaces. However, the LOSC cannot work the miracle of regulating those activities that were not foreseeable in the period when it was being negotiated. At this time, very little was known about the uses of the genes of marine organisms. The expressions 'genetic resources' and 'bioprospecting'57 do not appear in any of the LOSC provisions. 
It is a matter of fact that the term 'activities' in the Area is defined in the LOSC as 'all activities of exploration for, and exploitation of the resources of the Area' (Article 1(1)) and that the term 'resources' of the Area is defined as 'all solid, liquid or gaseous mineral resources in-situ in the Area at or beneath the sea-bed, including polymetallic nodules' (Article 133,a). This means that the present LOSC regime of common heritage of mankind does not include the non-mineral resources of the Area and that the rules envisaged for the exploration and exploitation of mineral resources cannot be extended to other resources located therein. However, this does not prevent States from extending the principle of common heritage of mankind to newly discovered resources not covered by the LOSC, if they wished to do so. This would lead to a change of the present LOSC frontier between the Area, as the common heritage of mankind, and other areas within national jurisdiction as zones of predominantly exclusive concern. The scope of the regime of the Area is already today broader than it may be believed at first sight. Under the LOSC, the legal condition of the Area as common heritage of mankind has an influence also on the regulation of activities that, although different from mining activities, are located in this maritime space. The regime of the Area encompasses subjects that are more or less directly related to mining activities, such as marine scientific research (Article 143(1)), the preservation of the marine environment (Article 145) and the protection of underwater cultural heritage (Article 149). As far as the first two subjects are concerned, it is difficult to draw a clear-cut distinction between what takes place on the seabed and what occurs in the superjacent waters.

Yet, extension of the principle of common heritage of mankind to the non-mineral resources of the Area would be a progressive evolution within the spirit of the LOSC, that is a treaty based on General Assembly Resolution $2749(\mathrm{XXV})^{58}$ and aiming at contributing to the realization of a just and equitable international economic order which takes into account the interests and needs of mankind as a whole and, in particular the special interests and needs of developing countries, whether coastal or land-locked' (LOSC preamble). While a specific regime for genetic resources is lacking, the aim of sharing the benefits among all States can still be seen as a basic objective embodied in the spirit of the Losc. Also in the field of genetic resources, the application of the principle of freedom of the sea, that is based on a first-come-firstserved' or 'freedom-of-fishing-for-resources' approach, leads to inequitable

$5^{8}$ Under this resolution, all the resources of the seabed beyond national jurisdiction fall under the common heritage of mankind regime. The resolution does not make any distinction between mineral and non-mineral resources. 
consequences. New cooperative schemes, including provisions on access and sharing of benefits, could be envisaged as the basis for the future regime on marine genetic resources beyond national jurisdiction. This would also be in full conformity with the principle of fair and equitable sharing of the benefits arising out of the utilization of genetic resources, set forth in Article 1 of the Convention on Biological Diversity and in Article 10 of its 2010 Nagoya Protocol on access to genetic resources and the fair and equitable sharing of benefits arising from their utilization. ${ }^{59}$ While the Nagoya Protocol does not apply to areas beyond national jurisdiction, it could become a source of inspiration for a future regime applying to resources located in such areas.

Given the difficulties and intricacies of many of the issues under discussion, the present negotiations require a spirit of moderation and efforts of constructive imagination by the States involved. It is not surprising if, in this preliminary stage of the discussions, the best way to address several crucial questions has not yet materialized. However, if the future agreement will ever be adopted and enter into force, it could lead to a major improvement in international law of the sea and a more equitable system of exploitation of marine resources. The regime of common heritage of mankind could be enlarged to cover also other resources. This confirms that the challenges posed by international law of the sea are to be found in the practical capacity of States to adapt and change old 'frontiers' to conform to new needs.

591992 Convention on Biological Diversity, 1760 UNTS 79; Article 10 of the 2010 Nagoya Protocol reads: 'Parties shall consider the need for and the modalities of a global multilateral benefit-sharing mechanism to address the fair and equitable sharing of benefits derived from the utilization of genetic resources and traditional knowledge associated with genetic resources that occur in transboundary situations or for which it is not possible to grant or obtain prior informed consent. The benefits shared by users of genetic resources and traditional knowledge associated with genetic resources through this mechanism shall be used to support the conservation of biological diversity and the sustainable use of its components globally'. 